\title{
Sleep problems in a sample of children with developmental disorders, before and during the COVID-19 pandemic
}

\author{
M. Belén Micheletti, M.D. ${ }^{a}$, Pablo Cafiero, M.D. ${ }^{a}$, Silvana Nápoli, M.D. ${ }^{a}$, \\ Celina Lejarraga, M.D. ${ }^{a}$, Paula Pedernera Bradichansky, M.D. ${ }^{a}$, M. Paula Vitale, M.D. ${ }^{a}$, \\ M. Gabriela Urinovsky, M.D. ${ }^{a}$, Anabella Escalante, M.D. ${ }^{a}$ and Estela Rodríguez, M.D. ${ }^{a}$
}

\begin{abstract}
Sleep problems (SPs) are common, especially among children with developmental disorders (DDs), and affect their functioning and quality of family life. Pediatricians play a major role in their management.

Objective. To define the frequency and types of SPs in a sample of children with DDs, determine the proportion of pediatricians who addressed such difficulties, assess the effects of sleep hygiene ( $\mathrm{SH})$, and describe the impact of the COVID-19 pandemic on sleep.

Population and methods. This was a quasiexperiment. SPs were diagnosed based on parents' concerns and/or clinical criteria. SH strategies were provided and their effect was assessed as per parents' reports and the Children's Sleep Habits Questionnaire in Spanish (CSHQ-S) before and after the strategies. During the COVID-19 pandemic, the SP outcome measure and SH-related outcome measures were measured again.

Results. A total of 161 children were included. The frequency of SPs was $55 \% ; 80 \%$ improved with SH. Eighty-three percent of children had a primary pediatrician; of these, $45 \%$ had consulted about sleep. During the COVID-19 pandemic, SPs increased and $\mathrm{SH}$ outcome measures changed. Conclusion. Approximately half of children with DDs have SPs; and the problem was only addressed by $45 \%$ of pediatricians. $\mathrm{SH}$ was beneficial for most children, so pediatricians' role seems critical. During the COVID-19 pandemic, SPs increased, probably as a result of its environmental impact on children with DDs. Key words: sleep, neurodevelopmental disorders, child development, sleep hygiene.
\end{abstract}

http: / / dx.doi.org/10.5546/ aap.2021.eng.296

E-mail address:

M. Belén Micheletti, M.D.: belenmicheletti@gmail. com

Funding:

Research fellowship granted by the Sociedad Argentina de Pediatría.

Conflict of interest:

None.

Received: 8-13-2020

Accepted: 1-14-2021

\section{INTRODUCTION}

Sleep is critical for neurodevelopment. It is essential in different processes, such as brain plasticity, attention, memory, learning, emotion regulation, stress response, energy recovery, growth, and tissue repair. ${ }^{1,2}$ Sleep takes part in an optimal immune system functioning, endocrine-metabolic regulation, and cardiovascular health. ${ }^{1}$ During the first years of life, it is children's main activity. ${ }^{3}$ Sleep requirements decrease with age. Reference values have been established for 0-18-year-old subjects, with percentiles between 2 (lower limit) and 98 (upper limit). ${ }^{4}$ Sleep is affected by individual, family, structure (bed, lighting, temperature, housing), and education factors, treatments, sociocultural characteristics (e.g., extended social hours), stress, and technology, being screen exposure (social networks, TV, etc.) a relevant factor. ${ }^{5-9}$

A sleep problem (SP) is defined as "any sleep pattern that is deemed unsatisfactory by parents, children or their pediatrician". ${ }^{10}$ According to the international bibliography, the prevalence of SPs is $25 \%$ in children younger than 5 years, and was $37.4 \%$ in a local study. ${ }^{11}$ Difficulties in terms of behavior, communication, sensory integration, and anxiety, which are common among children with developmental disorders (DDs), predispose them to have SPs, which have been described as frequent $(50-80 \%)$ and persistent in this population. ${ }^{12-14}$ In turn, SPs may worsen the manifestations mentioned before, thus leading to higher levels of fatigue, depression, and stress and 
having a negative impact on functioning and quality of family life. $12,13,15$

SPs are currently underdiagnosed. ${ }^{16}$ Pediatricians play a major role in their detection and management and may promote sleep hygiene $(\mathrm{SH})$ strategies, known as "daily activities that affect sleep through physiological factors" ${ }^{10}$ Lack of knowledge of such strategies may result in unnecessary consultations or tests. ${ }^{17}$

\section{OBJECTIVES}

A. To define the frequency and types of SPs in a clinical sample of children with DDs.

B. To determine the proportion of pediatricians who addressed such difficulties.

C. To assess the effectiveness of $\mathrm{SH}$ strategies.

D. To describe the impact of the COVID-19 pandemic on sleep.

\section{POPULATION AND METHODS}

This was a quasi-experimental (before and after) study. The population was made up of girls and boys with DDs aged 1-6 years who attended the Department of Interdisciplinary Neurodevelopment Clinics (DINC) of Hospital de Pediatría S.A.M.I.C. "Prof. Dr. Juan P. Garrahan" between July 2019 and March 2020 with followup up to July 2020. The sample was selected by convenience.

\section{Procedures and instruments}

During the medical visit, families completed a questionnaire about their children's sleeping habits (Annex 1) guided by the interviewer; after this, they gave their objective opinion about their concern regarding SPs using a visual analog scale (VAS) (Annex 2). Those who met the criteria for SPs went on to a second stage, during which they received guidance on $\mathrm{SH}$ strategies (manual developed by the DINC, Annex 3), answered questions about their primary pediatrician's approach to sleep (Annex 4), and completed the Children's Sleep Habits Questionnaire, Spanish version (CSHQ-S) ${ }^{18}$ (Annex 5) to obtain a score that may be compared to that obtained after the intervention (SH). One month after implementing $\mathrm{SH}$ strategies, the families of children with SPs participated in a third stage, during which they completed a questionnaire about the strategies provided (Annex 6), the VAS about parents' concern, and the CSHQ-S.

The questionnaires about sleep habits, the primary pediatrician's approach, and the usefulness of SH strategies were developed by the study authors. It should be noted that questionnaires were not pilot tested in advance.

After the COVID-19 lockdown was established, the families of children with SPs referred that they had difficulties implementing $\mathrm{SH}$ and that SPs had worsened. For this reason, a request was submitted to the Research Ethics Review Committee to measure the SP outcome measure and $\mathrm{SH}$-related outcome measures again and a new questionnaire was developed (Annex 7), which was sent electronically to all the families participating in the study 60 days after the COVID-19 lockdown started, including those who did not meet the SP criteria. Answers were compared to those collected during the first stage.

\section{1) Primary outcome measures}

1.1) Sleep problem:

1.1.1) Parents' concern: Parents were asked to select the most representative answer of the problem using a 5-option VAS (Annex 2).

1.1.2) Clinical criteria: Delay of more than 20 minutes to fall asleep ${ }^{19,20}$ and / or 1 or more nocturnal awakenings that last 20 minutes or more in total. ${ }^{21}$

1.2) Improvement in SPs with SH habits: Two questions were asked: "In your opinion, did the child's sleep improve?" and "Is sleep still a problem for you?" Respondents could choose 1 of the 5 options of the VAS (so that it could be compared to the one selected before the intervention). To check if there was a significant difference in the sample before and after the intervention, the mean score obtained in the CSHQ was compared (questionnaire for parents about their children's sleep habits, validated for children aged 2-10 years ${ }^{22}$ and in Spanish $^{23}$ ).

\section{2) Secondary outcome measures}

2.1) Categorization of SPs: Based on Navarro's classification ${ }^{10}(2$ or more SPs per child could be selected):

2.1.1) A child who has difficulty falling asleep: insomnia.

2.1.2) A child who experiences abnormal episodes during sleep: nightmares, night terrors, sleep-talking, sleepwalking, enuresis or movements.

2.1.3) A child who falls asleep during the day.

2.2) Sociodemographic outcome measures: sex; age; medical certificate of disability; 
social insurance program; educational setting ${ }^{24}$ (average number of years of education of individuals older than 25 years sharing the household, classified into low: $<6.99$ years, middle: $7-11.99$ years, and high: $\geq 12$ years); social stratification (GRAFFAR) ${ }^{25}$ : I-II-III-IV-V; unmet basic needs, ${ }^{26}$ family function-APGAR ${ }^{27}$ : normal, mild, moderate or severe dysfunction; attending an educational institution: yes or no; specific treatment for the child's DD (speech therapy, educational psychology, psychology, occupational therapy).

2.3) Biological outcome measures: gestational age; low birth weight for gestational age; genetic diagnosis; drugs (excluding those indicated for SPs).

2.4) Neurodevelopment: Diagnosis of DDs by DINC healthcare providers specialized in development and behavior, defined as per the Diagnostic and Statistical Manual of Mental Disorders, fifth edition, (DSM-5) ${ }^{28}$ and the Diagnostic Classification of Mental Health and Developmental Disorders of Infancy and Early Childhood, (DC: 0-5 $\left.5^{\mathrm{TM}}\right) .^{29}$

\section{3) Intervention: $S H$ strategies: Table 1}

The sample size estimated with the PiFace software, to meet objective A, was 120, based on a theoretical value of SP prevalence among children with DDs of $75 \% 12,14$ and a power of $95 \%$; to meet objective C, the estimated sample size was 43, to determine a 5-point reduction in the CSHQ-S score, ${ }^{30,31}$ with a 0.05 alpha value and a power of $90 \%$.

Categorical outcome measures were described as absolute values and frequencies, while numerical outcome measures, as mean and standard deviation. For the statistical analysis, the odds ratio (OR) and its corresponding confidence

\section{TABLE 1. Sleep hygiene strategies}

1. Establish a 30-minute bedtime routine following a regular schedule (up to 1 hour time difference).

2. Do relaxing activities before bedtime.

3. Use visual schedules.

4. Avoid screen exposure during the night.

5. Arrange a low noise and dimly lit room.

6. Avoid stimulating meals late in the day.

7. Avoid long naps.

8. Increase light exposure in the morning.

9. Reduce fluid intake before sleep.

10. Avoid going to bed immediately after eating.

Developed by the authors. interval (CI) was used to assess the relation to risk factors, using the $\chi^{2}$ test; and the $t$ test for paired samples was used to assess the effectiveness of $\mathrm{SH}$ strategies. The RStudio software was used. ${ }^{32}$

Participation was voluntary, and a written informed consent was obtained. The protocol was approved by the Hospital Bioethics Committee.

\section{RESULTS}

A total of 161 families were interviewed and $100 \%$ responded. Figure 1 shows the study flow chart. Demographic and biological characteristics are described in Table 2. Among children older than 3.5 years, $91 \%$ were attending an educational institution. The most common comorbidities were congenital heart disease (15\%) and epilepsy

TABLE 2. Demographic characteristics and biological history $(n=161)$

\begin{tabular}{|c|c|}
\hline Parameters & $\%(\mathrm{n})$ \\
\hline \multicolumn{2}{|l|}{ Sex: } \\
\hline Male & $67 \%(108)$ \\
\hline Age in months: mean (SD) & $50( \pm 16)$ \\
\hline \multicolumn{2}{|l|}{ Place of residence } \\
\hline Autonomous City of Buenos Aires & $8.5 \%(13)$ \\
\hline Greater Buenos Aires & $82 \%(132)$ \\
\hline Province of Buenos Aires & $4.5 \%(7)$ \\
\hline Other provinces & $5 \%(8)$ \\
\hline \multicolumn{2}{|l|}{ Education level } \\
\hline Low & $7 \%(11)$ \\
\hline Middle & $76 \%(123)$ \\
\hline High & $17 \%(27)$ \\
\hline Unmet basic needs & $20 \%(32)$ \\
\hline Social insurance program & $51 \%(82)$ \\
\hline Medical certificate of disability & $48 \%(77)$ \\
\hline $\begin{array}{l}\text { Medical certificate of disability }+ \text { social } \\
\text { insurance program }\end{array}$ & $30 \%(47)$ \\
\hline \multicolumn{2}{|l|}{ Social stratum as per Graffar's method } \\
\hline High & $0.5 \%(1)$ \\
\hline Middle-high & $8 \%(13)$ \\
\hline Middle-low & $57 \%(92)$ \\
\hline Working & $32 \%(51)$ \\
\hline Underclass & $2.5 \%(4)$ \\
\hline \multicolumn{2}{|l|}{ Family APGAR } \\
\hline Normal & $47 \%(75)$ \\
\hline Mild functional disability & $32 \%(51)$ \\
\hline Moderate functional disability & $14 \%(23)$ \\
\hline Severe functional disability & $7 \%(12)$ \\
\hline More than 3 people in the same bedroom & $63 \%(103)$ \\
\hline Prematurity & $19 \%(30)$ \\
\hline Low birth weight for gestational age & $20 \%(32)$ \\
\hline Confirmed genetic diagnosis & $11 \%(1)$ \\
\hline Comorbidity (associated medical conditions) & $65 \%(105)$ \\
\hline Previous medication (not related to sleep) & $22 \%(35)$ \\
\hline
\end{tabular}




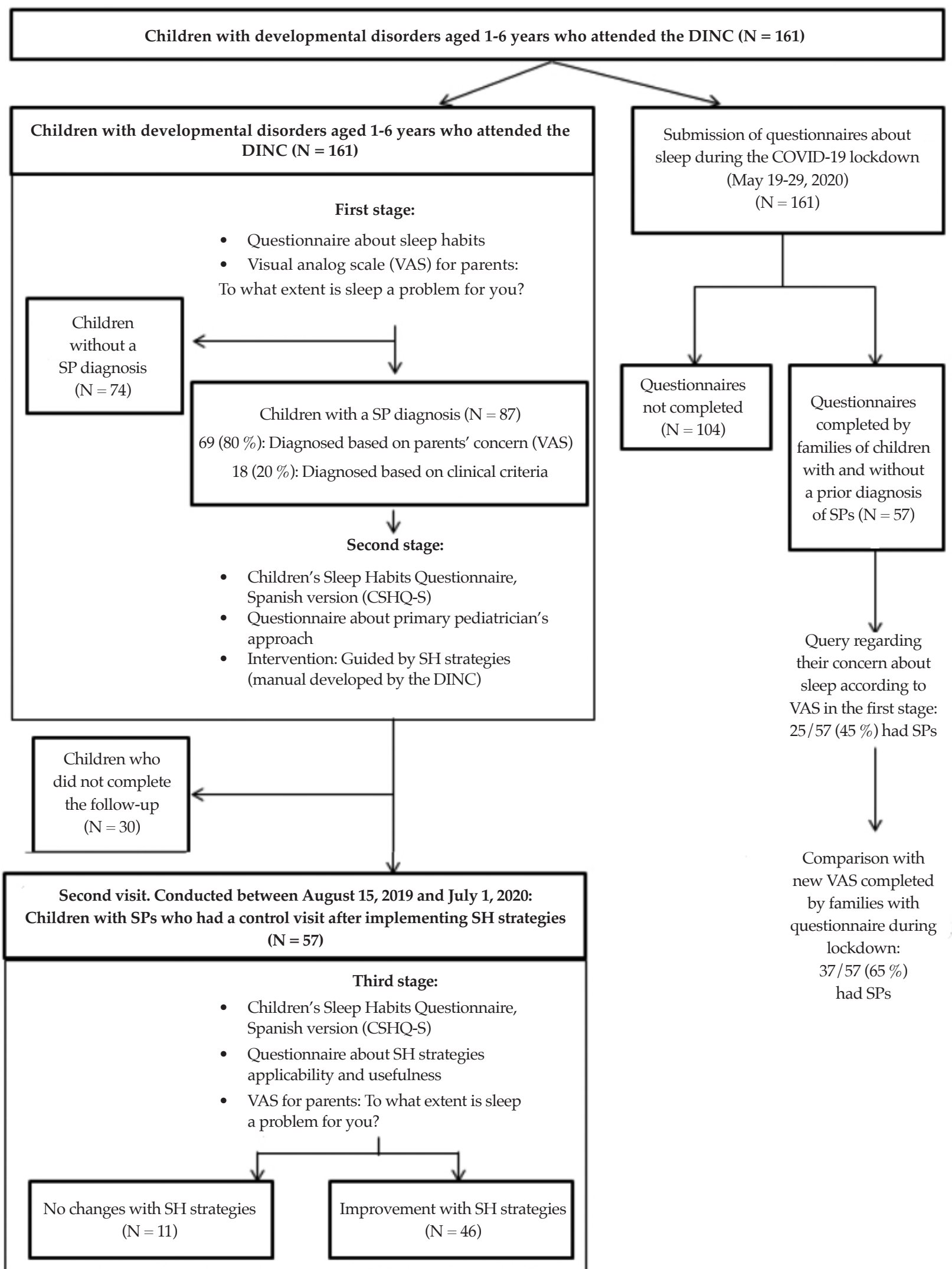


(12\%) (Table 3). Neurodevelopment-related diagnoses are shown in Table 4.

Eighty-three percent $(133 / 161)$ of children had a primary pediatrician; of these, $45 \%(60 / 133)$ had consulted about sleep. The recommendations for this included waiting $(30 \%=18 / 60)$, bedtime routine $(6 \%=4 / 60)$, specialist consultation $(5 \%=3 / 60)$, and others (talking to therapists and tidying the room) $(12 \%=7 / 60)$.

The total number of sleep hours was 10.5 hours (SD \pm 2$)$. Also, $53 \%$ of children $(86 / 161)$ took a 2-hour nap (SD \pm 1$)$; of these, $37 \%$ (32/86) did it after 4 p.m., with a mean age of 43 months $( \pm 14)$. The total number of screen exposure hours per day was $2.5(\mathrm{SD} \pm 1)$. In relation to this, $62 \%(100 / 161)$ had a TV in their bedroom; $70 \%(112 / 161)$ used screens after 8 p.m., and $56 \%$ (90/161) fell asleep in front of a screen (TV or mobile phone). In addition, $36 \%(58 / 161)$ practiced co-sleeping, with a mean age of 47 months $(S D \pm 14)$. The reasons for this were structural availability (15\%), habits $(7 \%)$, fear due to the child's underlying condition (7\%), and "reactive co-sleeping" in response to a problematic behavior $(46 \%)$.

The prevalence of SPs in children with DDs aged 1-6 years was $55 \%(87 / 161)$.

\section{Classification of SPs according to Navarro ${ }^{10}$}

A. A child who has difficulty falling asleep (51 \% = 82/161): $40 \%$ (64/161) fell asleep after 20 minutes. A significant difference was observed between taking a nap before 4 p.m. (25 minutes) and after 4 p.m. (65 minutes)

TABLE 3. Comorbidities in the studied population $(n=161)$

\begin{tabular}{lc}
\hline Comorbidity & $\%$ (n) \\
\hline Congenital heart disease & $16 \%(24)$ \\
Epilepsy & $12 \%(19)$ \\
Chronic respiratory diseases & $8 \%(12)$ \\
Obstructive sleep apnea syndrome & $4.5 \%(7)$ \\
Short stature & $4 \%(6)$ \\
Underweight & $2 \%(3)$ \\
Obesity & $2 \%(3)$ \\
Gastroesophageal reflux & $2 \%(3)$ \\
Chronic diarrhea & $2 \%(3)$ \\
Swallowing disorder & $1.5 \%(2)$ \\
Constipation & $1.5 \%(2)$ \\
Myelomeningocele & $0.6 \%(1)$ \\
Recurrent abdominal pain & $0.6 \%(1)$ \\
Parasitic disease & $0.6 \%(1)$ \\
Other comorbidities & $33 \%(51)$ \\
No comorbidities & $36 \%(56)$ \\
\hline
\end{tabular}

$(p<0.001)$. In addition, $36 \%(58 / 161)$ woke up 1 or more times per night, 5 nights / week $(S D \pm 2)$, for a mean total duration of 40 minutes. The most common events for sleep initiation were needing an adult companion $(51 \%=82 / 161)$, resisting going to bed $(33 \%=53 / 161)$, and needing an object or stuffed toy $(33 \%=53 / 161)$.

B. A child who experiences abnormal episodes during sleep $(38 \%=61 / 161)$ : the most common events were "restless during sleep" $(48 \%=77 / 161)$, bruxism $(20 \%=32 / 161)$, sleep-talking $(16 \%=26 / 161)$, crying while sleeping $(12 \%=20 / 161)$, enuresis $(5 \%=8 / 161)$, nightmares $(1.2 \%=2 / 161)$, night terrors $(1.8 \%=3 / 161)$, and sleepwalking $(1.2 \%=2 / 161)$.

C. A child who falls asleep during the day $(17 \%=27 / 161)$ : referred as "the child falls asleep while in the kindergarten/school, watching TV or playing". All these situations were secondary to sleep deficit.

Among the 87 children in whom SPs were detected $(n=87), 20 \%$ of parents $(18 / 87)$ stated that "it was not a problem" in spite of meeting the clinical criteria, and this was more common among children younger than 3.5 years (odds ratio [OR]: 3, $95 \%$ CI: 1-9, $p=0.04)$. SPs were referred to as a "moderate", "severe" or "major" problem by $45 \%$ (39/87). The remaining $35 \%$ (30/87) defined SPs as a "mild" problem. Among the 87 children with SPs, a longitudinal follow-up was completed in 57 . With the implementation of $2( \pm 1)$ SH strategies, $80 \%(45 / 57)$ of parents indicated that SPs had improved. The most useful SH strategies were reducing screen hours and organizing a bedtime routine. A significant difference of 5 points was observed in the CSHQ-S score before and after the intervention (95\% CI: 2-7, $p=0.001$ ).

TABLE 4. Neurodevelopment categorical diagnoses $(n=161)$

\begin{tabular}{lc}
\hline Diagnoses & $\%$ (n) \\
\hline Global developmental delay/intellectual disability & $38 \%(61)$ \\
Language delay/disorder & $31 \%(50)$ \\
Autism spectrum disorder & $30 \%(49)$ \\
Hearing impairment & $8.5 \%(14)$ \\
Difficulties in behavioral regulation & $7 \%(11)$ \\
Cerebral palsy & $5 \%(8)$ \\
Behavioral disorder & $4 \%(6)$ \\
Developmental coordination disorder & $2.5 \%(4)$ \\
Low vision & $2.5 \%(4)$ \\
Attention deficit hyperactivity disorder & $1 \%(2)$ \\
\hline
\end{tabular}


A total of 57 questionnaires about the COVID-19 pandemic were collected. The comparison with the outcome measures obtained in the first visit showed an increase in parents' concern, from $45 \%(25 / 57)$ to $65 \%(37 / 57)$. No significant differences were observed in terms of the time between the initial visit and the pandemic between the group who described SPs during the pandemic (7.5 months) and the group that did not ( 8 months) $(p=0.6)$. A longer screen exposure (2.5-3.5 hours / day) and a lower adherence to the bedtime schedule (from $75 \%$ to $61 \%$ ) were observed. An increase was observed in the following events during sleep: crying (from $16 \%$ to $40 \%$ ), nightmares (from $4 \%$ to $35 \%$ ), and nocturnal awakenings (from $35 \%$ to $51 \%$ ).

Table 5 describes the risk factors that showed a significant relation to developing SPs.

\section{DISCUSSION}

The frequency of SPs observed in children with DDs $(55 \%)$ is consistent with that described in the international bibliography. ${ }^{12,13}$ To date, no national studies have been published. The most common type of SP was the child having trouble falling asleep, as described in children without DDs. ${ }^{10}$

Screen exposure is significantly associated with SPs, and it has been demonstrated that SPs serve as a liaison between screen use and behavioral problems. ${ }^{9,33}$ Therefore, the approach to this situation is very important in children with DDs, who have a higher risk for screen use, trouble to "let go", and light sensitivity.

In our population, the total number of sleep hours was between the $2^{\text {nd }}$ and $10^{\text {th }}$ percentiles ${ }^{4,10,13}$ and in the lowest range of the values recommended by the American Association of Sleep Medicine. ${ }^{34}$

Our study is consistent with the bibliography in terms of the significant association between SPs and co-sleeping, but it is difficult to establish the trend of such association. ${ }^{35}$ Surveyed families provided different reasons for practicing cosleeping: structural availability, habits, fear due to the child's underlying condition, and reactive co-sleeping in response to a problematic behavior. This has been more often described in children with DDs, which may be the result of the higher prevalence of such reasons. According to our results, the rate of co-sleeping was similar to that described in children with DDs in Turkey, ${ }^{19}$ but higher than that observed in children with typical development in Argentina, ${ }^{11}$ Colombia, ${ }^{36}$ and Spain, ${ }^{37}$ and in children with DDs in England. ${ }^{9}$

Although we did not use parental stress scales, half of the parents of children with SPs mentioned stress as a significant problem based on the VAS. It is important to note the rate of parents $(20 \%)$ who did not mention sleep as a problem but whose children met the clinical criteria for SPs, as observed in other studies. ${ }^{15,37}$ In our population, this was more common among children younger than 3.5 years. Some hypotheses may be the higher prevalence of co-sleeping at that age, more flexible morning schedules due to the lack of educational activities or parents' expectations in relation to sleep at an earlier age, which may be analyzed in future studies.

The impact of environmental factors on sleep is reflected in the significant relation between a moderate-severe family dysfunction and SPs (also

TABLE 5. Risk and protective factors for sleep problems $(n=161)$

\begin{tabular}{|c|c|c|c|}
\hline Outcome measure & OR $(95 \% \mathrm{CI})$ & $p$ & $\begin{array}{l}\text { Relation with } \\
\text { sleep problem }\end{array}$ \\
\hline Moderate-severe family dysfunction (APGAR) & $2(1-5)$ & 0.05 & Risk factor \\
\hline$>3$ people in the same bedroom (middle or critical overcrowding) & $2(1-4)$ & 0.02 & Risk factor \\
\hline No access to therapeutic team specialized in the child's DD & $2(1-4)$ & 0.05 & Risk factor \\
\hline TV in the bedroom & $2.5(1-5)$ & 0.01 & Risk factor \\
\hline Sleep with screens & $2(1-4)$ & 0.01 & Risk factor \\
\hline TV on during the night & $3.5(1-11)$ & 0.03 & Risk factor \\
\hline Screen use $>2.5$ hours & $3(2-6)$ & 0.001 & Risk factor \\
\hline Nap after 4 p.m. & $3.5(1-9)$ & $<0.001$ & Risk factor \\
\hline Exposure to natural light in the morning & $0.30(0.1-0.9)$ & 0.04 & Protective factor \\
\hline Maintain a regular bedtime schedule & $0.04(0-0.3)$ & $<0.001$ & Protective factor \\
\hline Parents without changes in mood during COVID-19 lockdown & $0.22(0.07-0.7)$ & 0.01 & Protective factor \\
\hline Parents with sleep difficulties during COVID-19 lockdown & $12(2-98)$ & $<0.01$ & Risk factor \\
\hline
\end{tabular}


observed in prior studies); ${ }^{14}$ and in the access to treatment (which evidences the importance of addressing DDs in a timely manner). Although $20 \%$ of participants had unmet basic needs, the middle-high educational setting may have acted as a protective factor.

Among the families contacted during the third stage of the study, $80 \%$ reported an improvement in SPs with SH. Although this is consistent with the bibliography ${ }^{14}(74 \%)$, it should be noted that follow-up was challenging and it was not possible to contact 30 families. Still, based on data obtained-which reached the estimated sample size-and the supporting bibliography, it may be concluded that most SPs in children with DDs respond to $\mathrm{SH}$ strategies and may be addressed by pediatricians, without the need, at least initially, of additional visits to specialists or drug interventions. The 5-point difference before and after the intervention in the total CSHQ-S score was also similar to that described in other studies. ${ }^{30,31}$ Since it was initially difficult to contact the families in person, the use of electronic means helped us to obtain more answers.

Based on these results, the authors propose using the algorithm shown in Annex 8 to establish the potential management during pediatric visits.

As observed in our study, other studies also found a low proportion of primary pediatricians who approached this topic. ${ }^{16,38}$ For this reason, given its consequences and prevalence, it is critical to include this problematic condition in pediatric training programs.

The findings related to the COVID-19 pandemic showed an increase in SPs, which is consistent with published studies in children with ASD for the same period, with a higher CSHQ-S score, a higher resistance to going to bed, and a delay in falling asleep. ${ }^{39}$ Other studies in children without $\mathrm{DDs}^{40}$ also showed a higher prevalence of SPs, and the factors associated with their reduction were $\mathrm{SH}$ strategies, a harmonious family atmosphere, and better intra-family communication.

This study had the following limitations: the absence of a control group in whom $\mathrm{SH}$ strategies were not implemented (not done for ethical reasons) and the use of the CSHQ-S, a questionnaire that has not been validated in children younger than 2 years $(5 / 161$ children were in this age group) or in Argentina, which is evident in words that do not sound local. With the questionnaires completed in person, questions were asked by the interviewer, who adapted them to others more common here. The use of the CSHQ-S was a priority because it is one of the most widely used questionnaires in infant sleep research, even in infants younger than 1 year. ${ }^{22}$

\section{CONCLUSION}

Approximately half of children with DDs have SPs, being insomnia the most common one; this was addressed by the pediatrician only in $45 \%$ of cases. SH was beneficial for most children, so pediatricians' role seems critical. During the COVID-19 pandemic, it was evident that SPs increased, probably as a result of its environmental impact on the sleep of children with DDs.

\section{Acknowledgments}

We would like to thank the Department of Interdisciplinary Neurodevelopment Clinics of Hospital de Pediatría S.A.M.I.C. "Prof. Dr. Juan P. Garrahan" and Carolina Cernadas and Noelia Soria, from the Associated Direction of Research and Teaching (Dirección Asociada de Docencia e Investigación, DADI).

\section{REFERENCES}

1. ValiensiSM. Variaciones fisiológicas del sueño. In:Medicina del Sueño en Niños y Adolescentes. Buenos Aires: Akadia; 2016:13-5.

2. Ordway MR, Sadler LS, Canapari CA, Jeon S, et al. Sleep, biological stress, and health among toddlers living in socioeconomically disadvantaged homes: A research protocol. Res Nurs Health. 2017; 40(6):489-500.

3. Bathory E, Tomopoulos S. Sleep Regulation, Physiology and Development, Sleep Duration and Patterns, and Sleep Hygiene in Infants, Toddlers, and Preschool-Age Children. Curr Probl Pediatr Adolesc Health Care. 2017; 47(2):29-42.

4. Iglowstein I, Jenni OG, Molinari L, Largo RH. Sleep duration from infancy to adolescence: reference values and generational trends. Pediatrics. 2003; 111(2):302-7.

5. Owens J. Sleep and sleep disorders in children. In: Carey W, Crocker A, Elias ER, Feldman H, Coleman W. Developmental-Behavioral Pediatrics. $4^{\text {th }}$ ed. Philadelphia: Saunders ELSEVIER; 2009.Pages.619-28.

6. Meltzer LJ, Montgomery-Downs HE. Sleep in the family. Pediatr Clin North Am. 2011; 58(3):765-74.

7. CardinaliDP. ¿Dormir (ono)es un problema social? In:Qué es el sueño. Ciudad Autónoma de Buenos Aires: Paidós; 2014.Pages.29-38.

8. Mindell JA, Meltzer LJ, Carskadon MA, Chervin RD. Developmental aspects of sleep hygiene: findings from the 2004 National Sleep Foundation Sleep in America Poll. Sleep Med. 2009; 10(7):771-9.

9. LinJ, Magiati I, ChiongSHR, SinghalS, et al. The relationship among screen use, sleep, and emotional/behavioral difficulties in preschool children with neurodevelopmental disorders. J Dev Behav Pediatr. 2019; 40(7):519-29.

10. Cruz Navarro IJ. Alteraciones del sueño en la infancia. AEPap. Congreso de Actualización Pediatría. 2019;307-19. [Accessed on: April 20 ${ }^{\text {th }}$, 2019] Available at: https:// www.aepap.org/sites/default/files/pags._307-320_ 
alteraciones_del_sueno.pdf

11. Convertini DG, Krupitzky S, Tripodi MR, Carusso LL. Trastornos del sueño en niños sanos. Arch Argent Pediatr. 2003; 101(2):99-105.

12. Reynolds AM, Soke GN, Sabourin KR, Hepburn S, et al. Sleep problems in 2- to 5-year-olds with autism spectrum disorder and other developmental delays. Pediatrics. 2019; 143(3):e20180492.

13. Herrmann S. Counting Sheep: Sleep disorders in children with autism spectrum disorders. J Pediatr Health Care. 2016; 30(2):143-54.

14. Spruyt K, Curfs L. Non-pharmacological management of problematic sleeping in children with developmental disabilities. Dev Med Child Neurol. 2015; 57(2):120-36.

15. Pin Arboledas G. El sueño del niño con trastornos del neurodesarrollo. Medicina (B Aires). 2019; 79 (Supl I):44 50.

16. Meltzer LJ, Johnson C, CrosetteJ, Ramos M, et al. Prevalence of diagnosed sleep disorders in pediatric primary care practices. Pediatrics. 2010; 125(6):e1410-8.

17. Lord C. Taking sleep difficulties seriously in children with neurodevelopmental disorders and ASD. Pediatrics. 2019; 143(3):e20182629.

18. Lucas dela Cruz L, Martínez-Vizcaino V, Álvarez-BuenoC, Arias-Palencia N, etal. Reliability and validity of theSpanish version of the Children's Sleep Habits Questionnaire (CSHQ-SP) in school-age children. Child Care Health Dev. 2016; 42(5):675-82.

19. Köse S, Yilzman H, Tuna Ocakoglu F, Burcu Özbaran N. Sleep problems in children with autism spectrum disorder and intellectual disability without autism spectrum disorder. Sleep Med. 2017; 40:69-77.

20. Malow B, Byars K, Johnson K, Weiss S, et al. A practice pathway for theidentification, evaluation, and management of insomnia in children, and adolescents with autism spectrum disorders. Pediatrics. 2012; 130 (Suppl 2):S106-24.

21. Pin Arboledas G, Soto Insuga V, Jurado Luque MJ, Fernández Gomariz C, et al. Insomnio en niños y adolescentes. Documento de consenso. An Pediatr. 2017; 86(3):165.e1-11.

22. Castro Dias C, Figueiredo B, Pinto TM. Children's Sleep Habits Questionnaire-Infant Version. J Pediatr (Rio J). 2018; 94(2):146-54.

23. Ledesma DL. A Spanish version of the Children's Sleep Habits Questionnaire (CSHQ). [Theses, Projects, and Dissertations]. California State University, San Bernardino; 2014. [Accessed on: February 10 $\left.0^{\text {th }}, 2019\right]$. Available at: https: / / scholarworks.lib.csusb.edu/cgi/viewcontent. cgi? article $=1083 \&$ context $=$ etd

24. Aguilera ME, Rodríguez LF. Diferenciales sociales en el acceso a la educación en Argentina. VIII Jornadas Argentinas deestudios de población. Tandil, Buenos Aires, 12-14 de octubre de 2005. [Accessed on: February $10^{\text {th }}, 2019$ ]. Available at: http:/ / www.redaepa.org.ar/jornadas/viii / AEPA/B14/ Aguilera-Rodriguez.pdf

25. Benítez Mesa MG, Dunia Dahdah MR. Evaluación del método de estratificación social Graffar-Mendez Castellano. [Graduate Dissertation]. Universidad Católica Andrés Bello. Caracas, 2011. [Accessed on: February 10 $\left.{ }^{\text {th }}, 2019\right]$. Available at: http:/ / biblioteca2.ucab.edu.ve/anexos/ biblioteca/marc/texto/AAS1798.pdf

26. Argentina. Dirección Nacional de Relaciones Económicas con las Provincias. Subsecretaría de Relaciones con Provincias. Ministerio de Economía y Finanzas Públicas de la Nación. Necesidades Básicas Insatisfechas (NBI). Información censal del año 2010. 2014. [Accessed on: February $\left.10^{\text {th }}, 2019\right]$. Available at: http://www2. mecon.gov.ar/hacienda / dinrep / Informes / archivos / NBIAmpliado.pdf

27. Suárez Cuba M, Alcalá Espinoza M. Apgar familiar: una herramienta para detectar disfunción familiar. Rev Med La Paz. 2014; 20(1):53-7.

28. American Psychiatric Association. Diagnostic and Statistical Manual Of Mental Disorders (DSM-5). $5^{\text {th }}$ ed. Arlington, VA: American Psychiatric Association Publishing; 2014.

29. ZERO TO THREE. Diagnostic Classification of Mental Health and Developmental Disorders of Infancy and Early Childhood (DC: 0-5). Washington, DC: ZERO TO THREE; 2016.

30. Roberts CA, Smith KC, Sherman AK. Comparison of online and face-to-face parent education for children with autism and sleep problems. J Autism Dev Disord. 2019; 49(4):141022.

31. Malow B, Adkins K, Reynolds A, Weiss S, et al. Parentbased sleep education for children with autism spectrum disorders. J Autism Dev Disord. 2014; 44(1):216-28.

32. RStudio Team. RStudio: Integrated Development Environment for R [Internet]. Boston, MA: RStudio, PBC.; 2020. [Accessed on: February 10 ${ }^{\text {th }}, 2019$ ]. Available at: http: / / www.rstudio.com/

33. Van der Heijden KB, Stoffelsen RJ, Popma A, Swaab H. Sleep, chronotype, and sleep hygiene in children with attention-deficit/ hyperactivity disorder, autism spectrum disorder, and controls. Eur Child Adolesc Psychiatry. 2018; 27(1):99-111.

34. Paruthi S, Brooks LJ, D'Ambrosio C, Hall WA, et al. Recommended amount of sleep for pediatric populations: a consensus statement of the American Academy of Sleep Medicine. J Clin Sleep Med. 2016; 12(6):785-6.

35. Jenni O, Fuhrer H, Iglowstein I, Molinari L, Largo R. A longitudinal study of bed sharing and sleep problems among Swiss children in the first 10 years of life. Pediatrics. 2005; 115(1):233-40.

36. Contreras Ramírez M, Muñoz Martínez L, Noreña Velásquez M, Aguirre Peña A, et al. Prevalencia de los trastornos del sueño en niños escolares de Sabaneta, Colombia. Iatreia. 2008; 21(2):113-20.

37. Aymerich de Franchesci CM, Miguel-Miguel C, Arroba Basanta ML, Arana Cañedo-Argüelles C, et al. Patrones de sueño de los niños sanos a los cuatro años: factores sociales y estilos de crianza. Rev Pediatr Aten Primaria. 2019; 21(84):343-56.

38. McDonald A, JosephD. Paediatric neurodisability and sleep disorders: clinical pathways and management strategies. BMJ Paediatr Open. 2019; 3(1):e000290.

39. Türkoğlu S, Uçar HN, Çetin FH, Güler HA, et al. The relationship between chronotype, sleep, and autism symptom severity in children with ASD in COVID-19 home confinement period. Chronobiol Int. 2020; 37(8):1207-13.

40. Dellagiulia A, Lionetti F, Fasolo M, Verderame C, et al. Early impact of COVID-19 lockdown on children's sleep: a 4-week longitudinal study.JClin Sleep Med.2020;16(9):163940. 
ANNEX 1

Questionnaire about sleep habits

(Developed by the authors)

1. Where does the child sleep?

2. How many people share the bedroom?

3. Are there any screens (TV, computer, mobile phone) in the bedroom?

a) $\mathrm{No}$

b) Yes: Is the TV on during the night?

4. How many hours per day does the child use screens (TV, computer, mobile phone, tablet)?

5. Does the child use them during the night?

a) $\mathrm{No}$

b) Yes: Up to what time?

6. Does the child have a bedtime routine?

7. Has the child ever had sleep problems?

8. Does anyone in the family have or had sleep difficulties?

9. Does the child sleep alone in their bed?

a) Yes

b) No: Who shares the bed with the child?

10. What time does the child go to bed?

a) Weeknights:

b) Weekends or holidays:

11 . Does the child resist going to bed?

12. Does the child need someone else in the bedroom in order to sleep?

13. Is the child afraid of sleeping alone?

14. Is the child afraid of sleeping in the dark?

15. Does the child need an object or stuffed toy to sleep?

16. Does the child need rocking or rhythmic movements to fall asleep?

17. Does the child take too long to fall sleep (more than 20 minutes)?

- No

- Yes:

a. How long?

b. What does the child do in the meantime?

18. Does the child wake up during the night?

- No

- Yes:

a. How many times per night?

b. How many nights per week?

c. For how long is the child awake?

d. What does the child do in the meantime?

e. Does the child go back to sleep on their own?
19. Does the child wake up crying or frightened?

20. Does the child snore?

- No

- Yes: How many nights per week?

21. Does the child make loud noises or have trouble breathing?

22. Does the child seem to stop breathing?

23. Does the child move or is the child restless during sleep?

24. Does the child complain about pain during the night?

a. Where?

25. Does the child move their body during the night?

26. Does the child grind their teeth?

27 . Does the child wet the bed?

28 . Does the child talk in their sleep?

29 . Does the child sleepwalk?

30. Does the child change bedrooms?

31. What time does the child wake up?

a. Weekdays:

b. Weekends or holidays:

32. Does the child wake up on their own or do you wake them up?

33. Does the child wake up angry?

34. Does the child have trouble getting out of bed?

35. Does the child have trouble sleeping away from home?

36. Does the child take a long time to become alert?

37. Is the child hungry in the morning?

38. Does the child take a nap?

a. No

b. Yes: For how many hours? At what time?

39. Total sleep hours:

a. Do you think it is too little? Too much? Adequate?

40. Does the child fall asleep during the day while doing other activities?

41. Does the child seem tired during the day? 


\section{ANNEX 2}

Visual analog scale for parents

To what extent is sleep a problem for you?

\begin{tabular}{|l|l|l|l|l|}
\hline Not a problem & A mild problem & $\begin{array}{c}\text { A moderate } \\
\text { problem }\end{array}$ & A severe problem & A major problem \\
\hline
\end{tabular}




\section{ANNEX 3}

Manual of Strategies to Improve Sleep

\section{STRATEGIES TO IMPROVE SLEEP}

\section{SLEEP IS VERY IMPORTANT IN CHILD DEVELOPMENT.}

Sleeping well will help them to:

- Be more alert

- Have better memory

- Learn better

- Have more energy during the day to do activities

- Be less angry

- Have a lower risk for obesity

- Grow better

- Have better defenses and develop fewer diseases

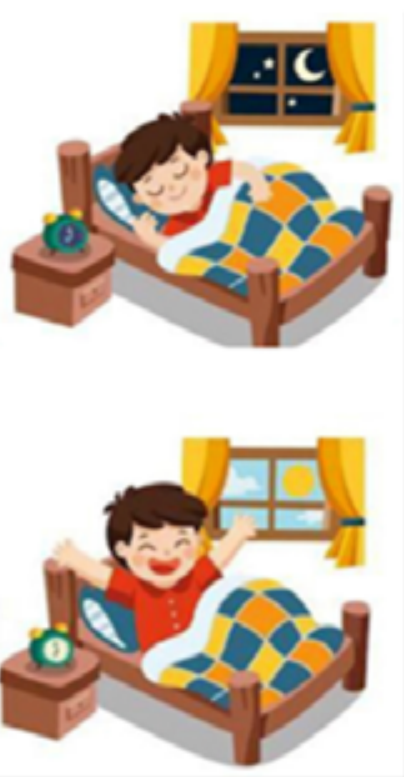

Sleep disorders are very common, especially in children who experience challenges in their development. Some children do not want to go to sleep when it is time, and parents "struggle" for several hours; other children have trouble falling asleep quickly and stay in bed playing; others wake up several times during the night to eat or play; and others only want to sleep with their parents or somewhere else than their bedroom... There are many situations like these, and they turn into a problem for the child (and their parents) because they do not get enough rest and the next day they fall asleep, have tantrums more often or become hyperactive.

You may not be sure whether some situations are normal or not, so let's start by taking a look at the characteristics of normal sleep. 


\section{CHARACTERISTICS OF NORMAL SLEEP}

Sleep patterns vary depending on the child's age and development:

Number of sleep hours:

\begin{tabular}{|cc|}
\hline Age & Sleep hours \\
\hline Newborn infant & $10-19 h$ \\
\hline $2-12$ months & $9-10 h$ (night) $+2-3 h$ (nap) \\
$1-3$ years & $9.5-10.5 h$ (night) $+2-3 h$ (nap) \\
$3-12$ years & $9-10 h$ \\
$13-18$ years & $9-9.5 h$ \\
\hline
\end{tabular}

JA. Mindell, JA Owens. A Clinical guide to Pediatric Sleep: Diagnosis and Management of Sleep Problems. $2^{\text {nd }}$ edition. 2009

Delay in falling asleep: Children should take, at most, 20 minutes to fall asleep.

$\checkmark$ Awakenings: Nocturnal awakenings are very common in infants younger than 6 months; after this age, they decrease gradually.

$\checkmark$ Naps: Naps are normal up to 3-4 years; after this age, many children stop sleeping during the day. Children younger than 18 months take 2 naps a day; then, only 1 nap in the afternoon. Naps should be always at the same time and not last more than 1-2 h (4 p.m. is time to go back to play). 
Sleep habits can be learned. If your child has sleeping problems, follow these steps to teach and help them sleep better.

STEP 1: Observe the child's sleep: Sleep schedule (page 4)

STEP 2: Strategies to be implemented ALWAYS: "THE 4 As" (page 5)

- Activities during the day

- Activities during the night

- A meal before bedtime

- A quiet environment

STEP 3: Organize a routine (page 7)

STEP 4: Implement the routine! Visual schedule (page 8)

STEP 5: Specific strategies for each case (page 11)

- "The child has trouble falling asleep"

- "The child wakes up during the night"

STEP 6: Reassess the child's sleep: Did anything change? (page 13)

\section{LET'S START!}




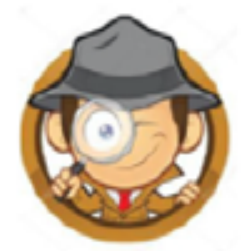

Every time something goes wrong, we have to review it in detail so that we may find a solution and fix it. The same thing happens with sleep. If you want your child to sleep better, first you have to watch them carefully and you'll find the problem you need to solve.

In the annex, you will find a "sleep schedule," where you can record anything related to sleep for 3-5 days: the time the child wakes up and goes to bed, noting when the child is asleep and awake, and the activities the child does before bedtime, in bed, and during the morning.

\section{Let's see an example:}

Fill in the time when the child sleeps $\mathrm{DI}$ and leave the time when the child is awake blank 1 . Use a down arrow $\downarrow$ to indicate when the child goes to bed and an up arrow $\uparrow$ when the child gets out of bed. S/H: Sundays or holidays.

Example: The child sleeps until 4 a.m. The child gets out of bed at 4 a.m. and goes back to bed at 4:15 a.m. The child stays awake until 5:30 a.m. and then falls asleep until 9 a.m. The child wakes up at 9 a.m. The child goes to bed at 3 p.m. and falls asleep at $3: 15$ p.m., and then wakes up at 4:30 p.m. The child goes to bed at 8:30 p.m. and sleeps from 9 p.m. to 11 p.m. The child is awake from 11 p.m. to 12 a.m.

\begin{tabular}{|l|l|l|l|l|l|l|l|l|l|l|l|l|l|l|l|l|l|l|l|l|l|l|l|l|l|}
\hline Day & Sn & 0 & 1 & 2 & 3 & 4 & 5 & 6 & 7 & 8 & 9 & 10 & 11 & 12 & 13 & 14 & 15 & 16 & 17 & 18 & 19 & 20 & 21 & 22 & 23 \\
\hline & & & &
\end{tabular}

Guía de Practica Cinica sebre Trastamas del Sueno an la intancia y Adolescencia en Atancion Primaria. Spain. 2011.

Once the registry is completed, you can objectively determine if there is a sleep problem, establish the type of sleep problem, and make sleep habit improvements. 


\section{ACTIVITIES DURING THE DAY}

Doing physical exercise and outdoor activities, exposed to natural light (playing in the park or backyard) will help the child rest better during the night and fall asleep faster.

\section{ACTIVITIES DURING THE NIGHT}

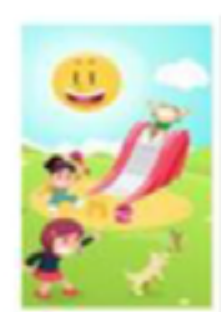

AVOID TV SHOWS, FILMS OR VIDEOS AND VIDEOGAMES THAT MAY EXCITE THE CHILD WITHIN 2 HOURS BEFORE BEDTIME.

Although the child may seem quieter while watching TV because they are not moving, their brain receives a high level of stimulation that prevents a good night's sleep.

\section{A MEAL BEFORE BEDTIME}

- Avoid large meals, candies, and soft drinks in the last hours of the day.

- Do not take the child to bed immediately after eating.

- Do not give the child too much liquid before bedtime.

\section{A QUIET ENVIRONMENT}

It is very important not to use the bed or bedroom as a punishment. If it is associated with punishment, it will be harder to get the child to sleep there.

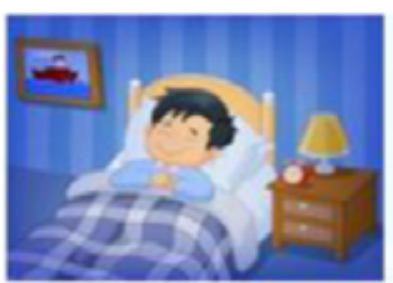


It has been demonstrated that a quiet environment helps children to sleep better. The bedroom must have:

\section{- $\quad$ A warm or adequate temperature depending on the season}

- $\quad$ Adequate ventilation and no smoke (such as cigarette smoke)

- $\quad$ Clothing: Choose comfortable clothes (consider textures, labels, layers of coat, etc.).

- $\quad$ Noises and lights:

- Avoid noises, unless the child likes a specific noise that helps them relax, e.g., fan noise.

- Little or no lights at all. If the child needs the lights on, you can use a table lamp with a dim light.

- Avoid electronic devices. Using screens delays sleep. A good idea is to replace screens with a story or book.

IDEALLY THERE SHOULD BE NO SCREENS

IN THE BEDROOM. 
A ROUTINE consists in organizing a set of activities that are repeated usually at the same time and in the same order. A bedtime routine should include activities that FACILITATE SLEEP. Repeating the routine every day will help the child sleep and rest better.

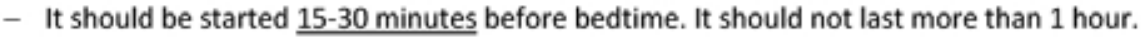

- The first activities may take place anywhere in the house, but the last activities should be in the child's bedroom, and it is better to get the child to bed before they fall asleep.

- Activities:

- Choose quiet activities to calm down the child, such as taking a bath, turning off the lights, rocking movements, listening to quiet music or a story.

- Sometimes, sensory stimulation activities may be useful because they may help the child to relax and fall asleep more easily. These may include proprioceptive stimulation exercises (massages using cream, brushes, sponges or simply the hand, putting pressure down the arms and/or legs; squeezing them with cushions; wrapping them with a quilt) or vestibular stimulation exercises (e.g., swinging).

- Before bedtime, it would be good for the child to pee in the bathroom, so that they do not feel the need to get up during the night.

- If any activity is harder, it is better to do it at the beginning of the routine, for example, taking a bath or brushing their teeth. 


\section{STEP 4: IMPLEMENT THE ROUTINE: VISUAL SCHEDULES}

Some people may wonder "How do I get my child to do this if they do not want to?" or "I have a hard time changing my child's routine, they get angry when I ask them to do something different." VISUAL SCHEDULES are very helpful in these situations.

A visual schedule explains the routine using images (pictures, drawings or actual objects) that represent each activity. It will help the child understand (both those with language skills and younger ones). Its preparation in advance helps the child to remain calm because they understand what will happen next and is a funnier and more striking lesson.

\section{Example of images selected for routine activities:}

1- Pajamas:

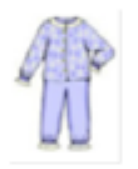

2-Peeing:

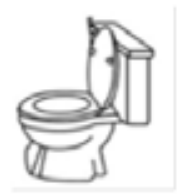

3- Washing hands:

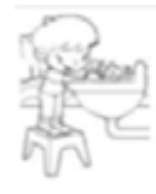

4- Brushing teeth:

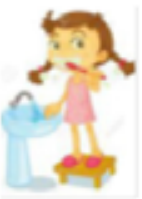

5- Going to bed:

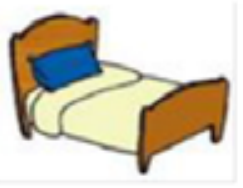

6- Favorite story:

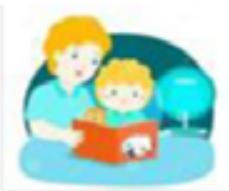

7- Sleeping:

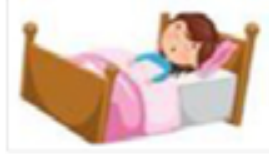

Then place one image next to the other, in the corresponding order. 
Examples of visual schedules with drawings:
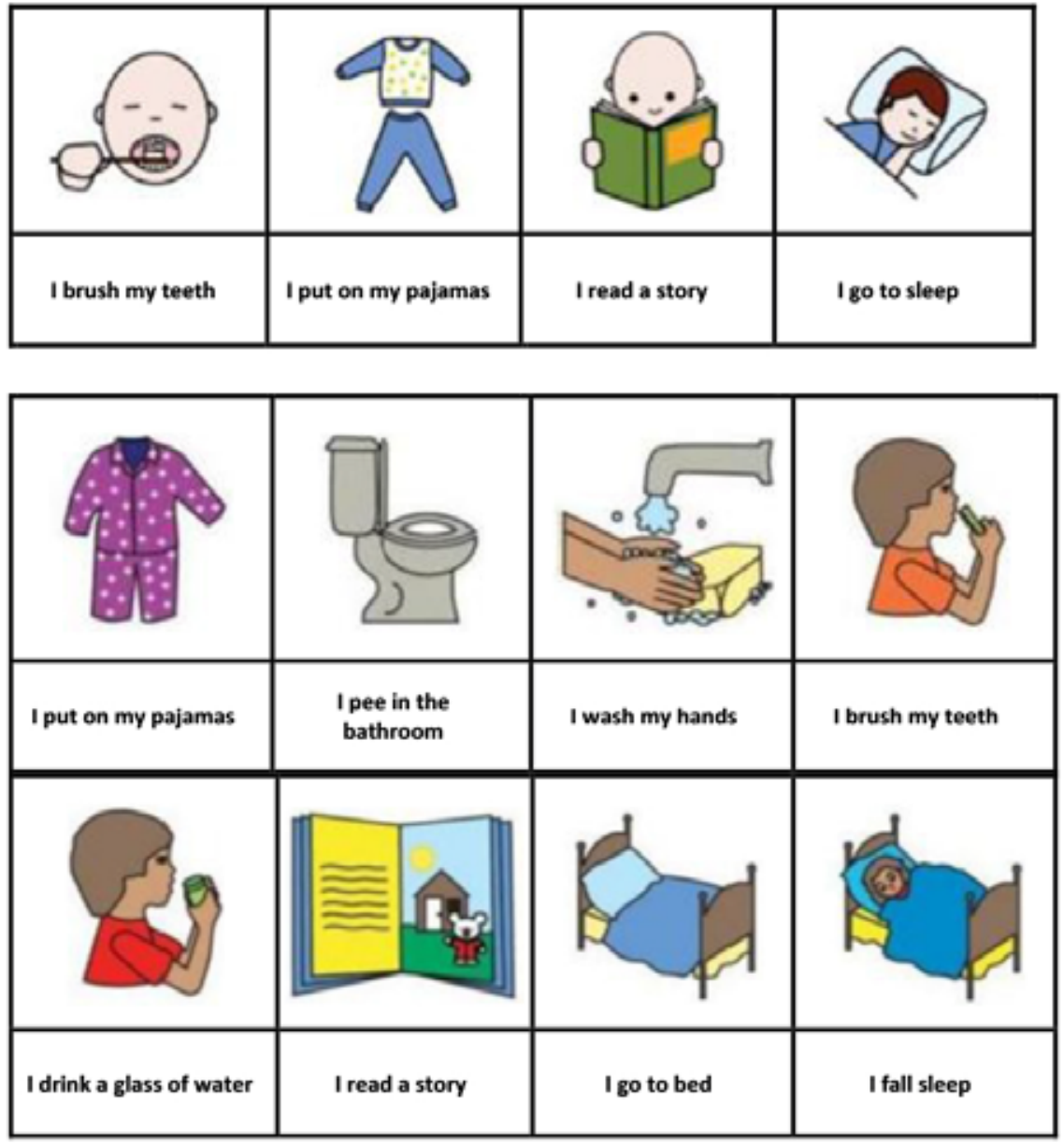

At the end of the visual schedule, you may give the child a reward, such as letting them have their favorite toy or stuffed animal. This may also be included in the visual schedule with a picture or drawing of the potential reward or a happy face.

\section{REWARDS OR PRIZES!}

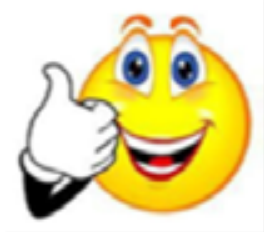

Any behavior that is "positively reinforced" will more likely be repeated. A positive reinforcement may be congratulating the child with a hug, tickling or a prize. While teaching the child a sleep habit, you should show them that there will be a prize. After the child completes the activity, show them that you are happy with it.

On the other side, "ignored" behaviors tend to diminish. If the child does something you want to change, pay little attention. 
For older children (older than 4-5 years), you may use the token economy technique: Every time the child completes a task, such as going to bed without watching TV but listening to a story, going to bed in time, staying in bed, etc., they may earn a happy face or drawing on a sticker chart; at the end of the week, they win a prize based on the number of stickers earned (e.g., 4 happy faces).

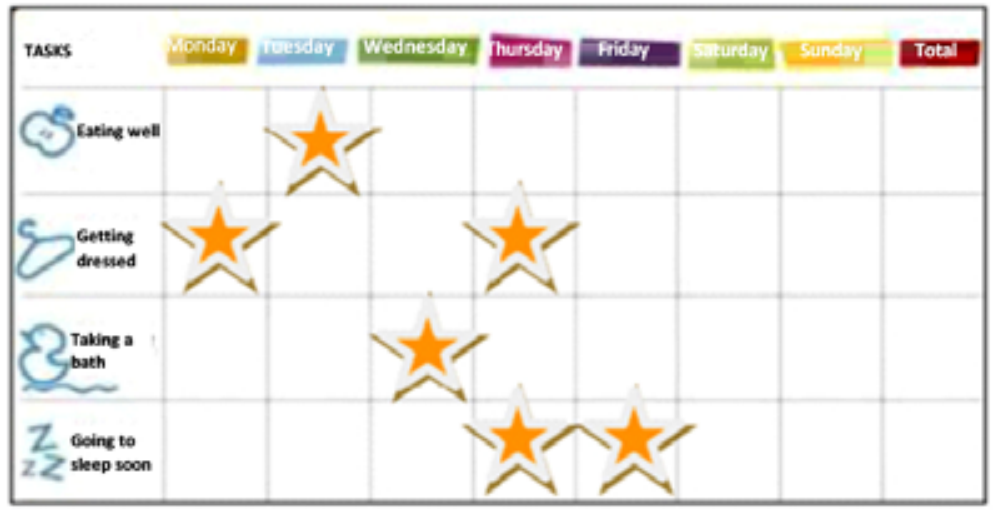

4 stars: 5 minutes of videogames

5 stars: Playing in the park

7 stars: Favorite toy

\section{STEP 5: SPECIFIC STRATEGIES FOR EACH CASE}

\section{"THE CHILD HAS TROUBLE FALLING ASLEEP"}

- For children who take a long time falling asleep, it is recommended to delay the bedtime while implementing the prior routine, so that the time spent awake in bed is not associated with another "activity." Once the child falls asleep within 20 minutes of going to bed, you may advance the bedtime at 15-minute intervals every 2-3 days.

For example, if you put the child to bed at 10 p.m. and they fall asleep around midnight, put them to bed at 11:30 p.m. after completing the routine and while doing a quiet activity in bed, such as reading a story. Once you get the child to fall asleep at midnight, advance the bedtime to 11:15 p.m., always performing the same routine. Once you get the child to fall asleep before 11:35 p.m., advance the bedtime to 11 p.m., and so on.

- If the child gets too much sleep during the day, they will not be tired enough to fall asleep at night. Make sure the child takes naps for less than 2 hours and is up by 4 p.m. And remember that as of 3-4 years old, they no longer need naps! 


\section{"THE CHILD WAKES UP MANY TIMES"}

- One of the most common situations is that, when a child wakes up crying, parents look for quick solutions, such as taking them to their room, feeding them or turning on the TV (many times to muffle the noise and prevent their siblings or someone else who has to work the next day from waking up). When the child cries or wakes up, give them time to fall back asleep on their own (count to 20). If the situation continues, you may try 1 incentive at a time, such as rhythmic patting, rocking movements or soft singing. It is recommended to maintain the bedroom in the same conditions and give the child something to help them go back to sleep. You may also repeat some of the activities performed as part of the bedtime routine.

- $\quad$ "Bedtime pass": For older children who wake up during the night, you may use a "pass" that they have to surrender if they change to your bedroom in the middle of the night. But if the child does not change to your bedroom, the next morning they may exchange it for an encouraging prize.

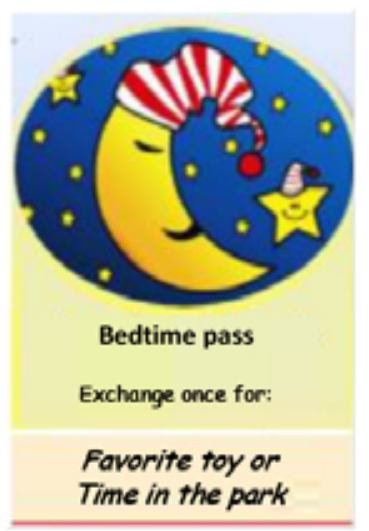

\section{STEP 6: REASSESS THE CHILD'S SLEEP: Did anything change?}

One month after implementing these strategies, it is time to reassess their effectiveness or whether it is necessary to make a change.

To obtain an objective opinion, make a new sleep schedule and this will allow us to check for improvements in relation to your concerns.

If you have any doubt or your concerns persist, talk to your child's pediatrician or therapists! 


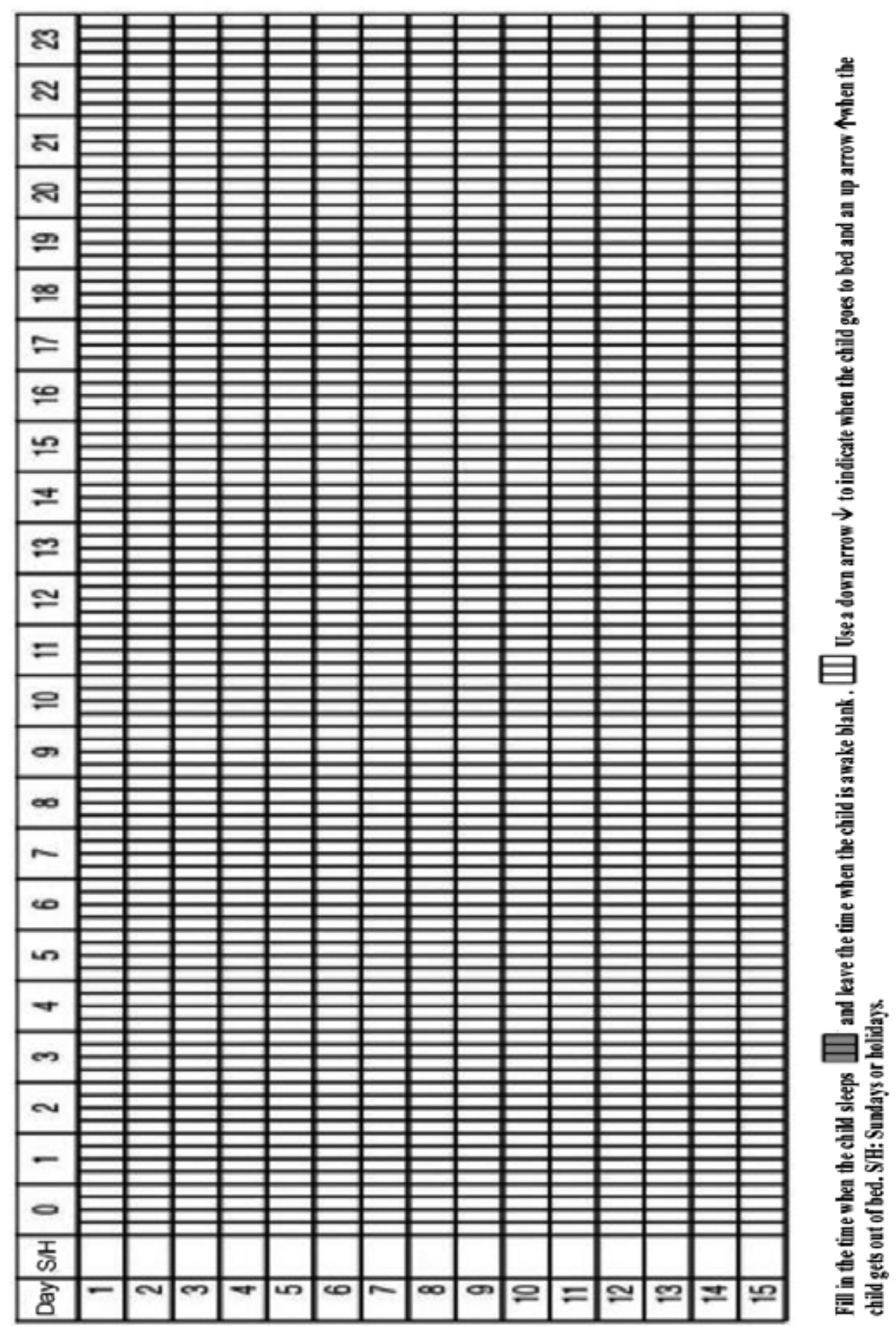


ANNEX 2: Images for visual schedules:

https://www.autismspeaks.org/sites/default/files/2018-10/sleep-quick-tips-spanish.pdf
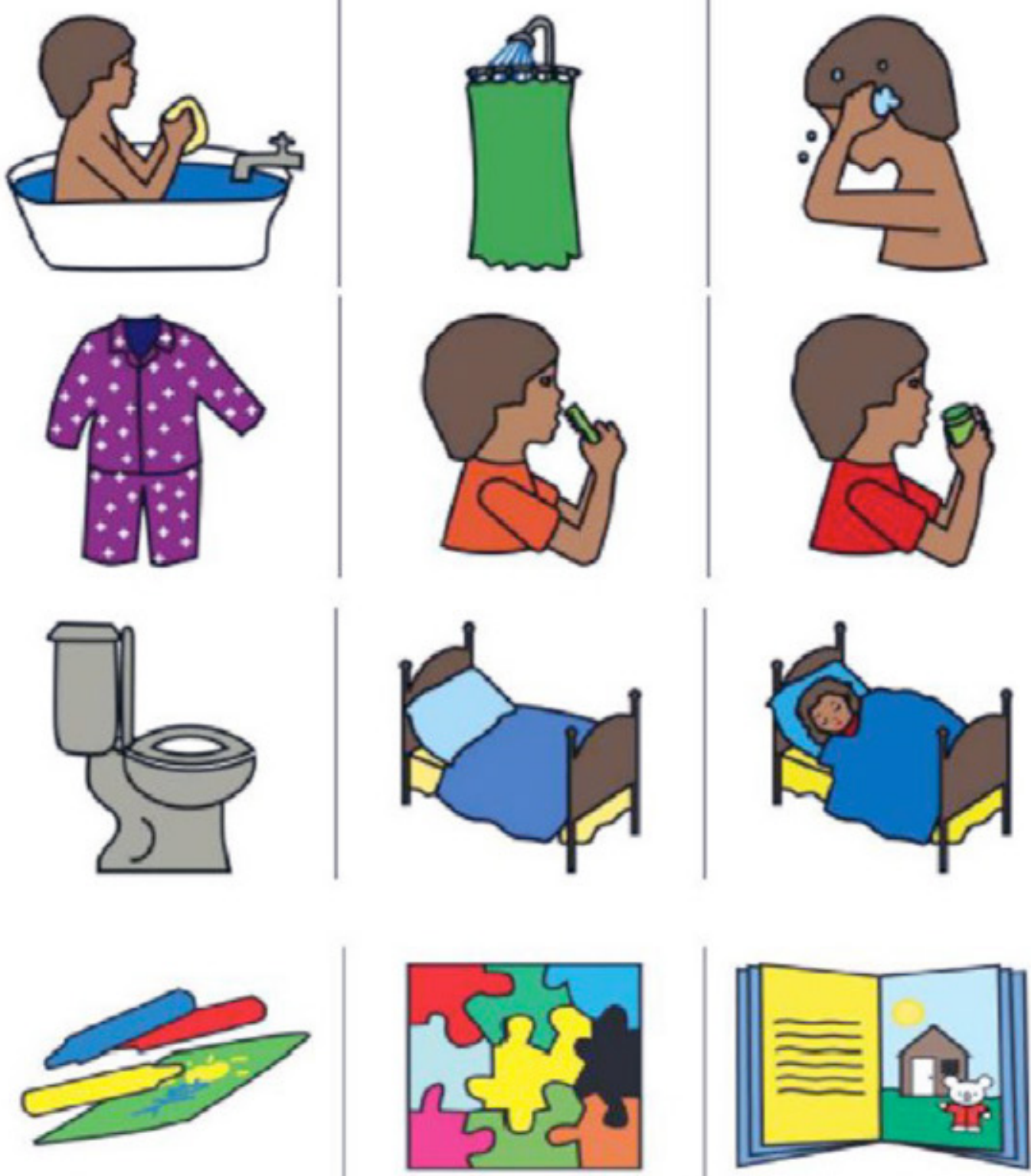


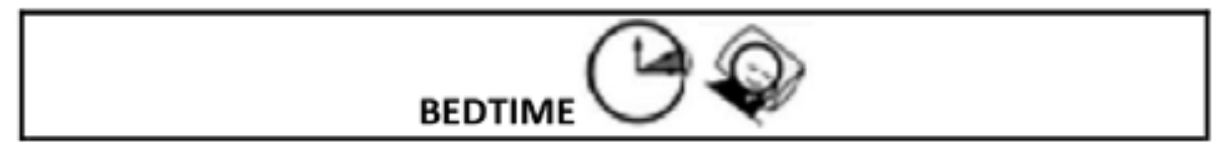

\begin{tabular}{|l|}
\hline 1. PUT ON PAJAMAS. \\
\hline 2. BRUSH YOUR TEETH. \\
\hline 3. DRINK A GLASS OF WATER. \\
\hline 4. GO TO BED. \\
\hline 6EAD A STORY. \\
\hline 9. GOODNIGHT KISS. \\
9. SWEET DREAMS!
\end{tabular}




\section{BIBLIOGRAPHY}

1. Autism Speaks.

https://www.autismspeaks.org/sites/default/files/2018-10/sleep-quick-tips-spanish.pdf

2. Encouraging good sleep habits in children with learning disabilities https://www.oxfordhealth.nhs.uk/wp-content/uploads/2014/05/Good-sleep-habits-forchildren-with-Learning-Difficulties.pdf

3. Mindell JA, Owens JA. A Clinical guide to Pediatric Sleep: Diagnosis and Management of Sleep Problems. $2^{\text {nd }}$ edition. 2009.

4. Valiensi SM. Medicina del sueño en niños y adolescentes. 1.å Edición. Buenos Aires: Editorial AKADIA; 2016. 29-42. 


\section{ANNEX 4}

Questionnaire for parents about the approach to sleep problems during the visit to the pediatrician (Developed by the authors)

1. During follow-up visits, does the pediatrician ask about your child's sleep regularly?

a. Yes: Go to question 2.

b. No: Go to question 3.

2. Did your concern about sleep first appear after the pediatrician asked about it?

a. Yes: Go to question 4.

b. No: Go to question 4 .

3. If the pediatrician did not ask about sleep, did you mention your concern spontaneously?

a. Yes: Go to question 4.

b. No: End the questionnaire here.

4. Did the pediatrician refer the child for a consultation?

a. No.

b. Yes: What specialty?

5. Did the pediatrician order any study?
a. No.
b- Yes: Which one?

6. What suggestions did the pediatrician make when you asked?
a. Nothing, just wait.
b. Organize a bedtime routine.
c. Reduce screen hours.
d. Other:

7. Did you notice changes after implementing the recommended strategies?
a. Yes.
b. No. 


\section{ANNEX 5}

Children's Sleep Habits Questionnaire, Spanish version (CSHQ-S)

Encuesta de habitos de sueño infantil

La siguientes preguntas están relacionadas con las costumbres de sueño de su hijo/a y sus posibles dificultades. Trate de recordar lo sucedido en la última semana para contestar esta encuesta. Si en esa semana hubiera habido alguna circunstancia que pudiera alterar el sueño (enfermedades, viajes, etc.) conteste la encuesta pensando en una semana habitual. Responda HABITUALMENTE si algo ocurre 5 o más dias por semana; responda A VECES si ocurre 2-4 veces por semana; responda RARO si no ocurre nunca o 1 vez a la semana.

Rellene los cuadritos para indicar la respuesta adecuada.

\begin{tabular}{|c|c|c|c|}
\hline Nombre del niño: & & & \begin{tabular}{|l} 
Fecha de \\
nacimiento
\end{tabular} \\
\hline Edad: & & & $\begin{array}{l}\text { Fecha de la } \\
\text { encuesta }\end{array}$ \\
\hline Encuesta hecha por & Madre & 무 & Observaciones \\
\hline & Padre & ㅁ & \\
\hline & Ambos & ㅁ & \\
\hline
\end{tabular}

\section{Acostarse}

Escriba la hora a la que se acuesta el niño/a:

\begin{tabular}{|l|l|}
\hline Días de labor & \\
\hline Dias festivos o fines de semana & \\
\hline
\end{tabular}

\begin{tabular}{|l|c|c|c|}
\hline & $\begin{array}{c}\text { Habitualmente } \\
\text { (5-7 dias a la } \\
\text { semana) }\end{array}$ & $\begin{array}{c}\text { A veces } \\
\text { (2-4 dias a } \\
\text { la semana) }\end{array}$ & $\begin{array}{c}\text { Raro } \\
\text { (0-1 dias a la } \\
\text { semana) }\end{array}$ \\
\hline El niño se acuesta siempre a la misma hora & $\square$ & $\square$ & $\square$ \\
\hline Se duerme antes de 20 minutos & $\square$ & $\square$ & $\square$ \\
\hline Se duerme en su cama & $\square$ & $\square$ & $\square$ \\
\hline Se duerme en la cama de algun hermano & $\square$ & $\square$ & $\square$ \\
\hline $\begin{array}{l}\text { Se duerme con balanceo o con movimientos } \\
\text { ritmicos }\end{array}$ & $\square$ & $\square$ & $\square$ \\
\hline $\begin{array}{l}\text { Necesita objetos especiales para dormirse } \\
\text { (muñecos, almohadas o sabanas especiales, etc.) }\end{array}$ & $\square$ & $\square$ & $\square$ \\
\hline $\begin{array}{l}\text { Necesita que esté el padre o la madre en la } \\
\text { habitación para dormirse }\end{array}$ & $\square$ & $\square$ & $\square$ \\
\hline $\begin{array}{l}\text { Está dispuesto a acostarse cuando es la hora de } \\
\text { ir a la cama }\end{array}$ & $\square$ & $\square$ & $\square$ \\
\hline Se resiste a ir a la cama cuando es la hora & $\square$ & $\square$ & \\
\hline $\begin{array}{l}\text { Pelea para no ir a la cama (grita, se niega a } \\
\text { acostarse, etc.) }\end{array}$ & $\square$ & $\square$ & $\square$ \\
\hline Tiene miedo a dormir a oscuras & $\square$ & $\square$ & $\square$ \\
\hline Tiene miedo a dormir solo & $\square$ & $\square$ & $\square$ \\
\hline
\end{tabular}

Conducta de sueño

Cantidad de horas de sueño por día sumando siestas y sueño nocturno (horas y minutos)

\begin{tabular}{|l|l|}
\hline Dias de labor & \\
\hline Dias festivos o fines de semana & \\
\hline
\end{tabular}

\begin{tabular}{|l|c|c|c|}
\hline & $\begin{array}{c}\text { Habitualment } \\
\mathrm{e} \\
\text { (5-7 dias a la } \\
\text { semana) }\end{array}$ & $\begin{array}{c}\text { A veces } \\
(2-4 \text { dias a la } \\
\text { semana) }\end{array}$ & $\begin{array}{c}\text { Raro } \\
\text { (0-1dias a la } \\
\text { semana) }\end{array}$ \\
\hline
\end{tabular}




\begin{tabular}{|l|c|c|c|}
\hline Duerme muy poco & $\square$ & $\square$ & $\square$ \\
\hline Duerme demasiado & $\square$ & $\square$ & $\square$ \\
\hline Duerme lo necesario & $\square$ & $\square$ & $\square$ \\
\hline Duerme todos los dias las mismas horas & $\square$ & $\square$ & $\square$ \\
\hline Se orina por la noche & $\square$ & $\square$ & $\square$ \\
\hline Habla durante el sueño & $\square$ & $\square$ & $\square$ \\
\hline $\begin{array}{l}\text { Está inquieto y se mueve mucho durante } \\
\text { el sueño }\end{array}$ & $\square$ & $\square$ & $\square$ \\
\hline Tiene sonambulismo & $\square$ & $\square$ & $\square$ \\
\hline $\begin{array}{l}\text { Va a otra habitación (padres, hermanos, } \\
\text { etc.) }\end{array}$ & $\square$ & $\square$ & $\square$ \\
\hline $\begin{array}{l}\text { Duerme en la cama de los padres o } \\
\text { hermanos }\end{array}$ & $\square$ & $\square$ & $\square$ \\
\hline Dice que tiene dolores durante el sueño & $\square$ & $\square$ & $\square$ \\
\hline En caso afirmativo decir dónde se queja & & & \\
\hline Tiene rechinar de dientes durante el sueño & $\square$ & $\square$ & $\square$ \\
\hline Ronca de manera ruidosa & $\square$ & $\square$ & $\square$ \\
\hline $\begin{array}{l}\text { Parece que deja de respirar durante el } \\
\text { sueño }\end{array}$ & $\square$ & $\square$ & $\square$ \\
\hline $\begin{array}{l}\text { Tiene a la vez ruidos fuertes y dificultad } \\
\text { respiratoria durante el sueño }\end{array}$ & $\square$ & $\square$ & $\square$ \\
\hline $\begin{array}{l}\text { Tiene dificultades para dormir fuera de } \\
\text { casa (vacaciones, casa de familiares, etc.) }\end{array}$ & $\square$ & $\square$ & $\square$ \\
\hline $\begin{array}{l}\text { El niño se queja de problemas con el } \\
\text { sueño }\end{array}$ & $\square$ & $\square$ & $\square$ \\
\hline $\begin{array}{l}\text { Se despierta durante la noche llorando, } \\
\text { sudando, asustado, etc. }\end{array}$ & $\square$ & $\square$ & $\square$ \\
\hline Se despierta asustado por pesadillas & $\square$ & $\square$ & $\square$ \\
\hline
\end{tabular}

Despertares nocturnos

\begin{tabular}{|l|c|c|c|}
\hline & $\begin{array}{c}\text { Habitualmente } \\
\text { (5-7 dias a la } \\
\text { semana) }\end{array}$ & $\begin{array}{c}\text { A veces } \\
\text { (2-4 dias a la } \\
\text { semana) }\end{array}$ & $\begin{array}{c}\text { Raro } \\
\text { (0-1 días a } \\
\text { la semana) }\end{array}$ \\
\hline Se despierta una vez por la noche & $\square$ & $\square$ & $\square$ \\
\hline Se despierta más de una vez por la noche & $\square$ & $\square$ & $\square$ \\
\hline $\begin{array}{l}\text { Se despierta y se queda dormido sin ayuda de } \\
\text { nadie }\end{array}$ & $\square$ & $\square$ & $\square$ \\
\hline
\end{tabular}

Anote la duración en minutos de los despertares nocturnos:

Despertar matutino

Escriba la hora a la que ser despierta habitualmente por la mañana:

Días de labor

Dias festivos o fines de semaana

\begin{tabular}{|l|c|c|c|}
\hline & $\begin{array}{c}\text { Habitualmente } \\
(5-7 \\
\text { dias/semana) }\end{array}$ & $\begin{array}{c}\text { A veces } \\
(2-4 \text { dias } \\
\text { semana) }\end{array}$ & $\begin{array}{c}\text { Raro } \\
\text { (0-1 días a } \\
\text { la semana) }\end{array}$ \\
\hline Se despierta por si mismo & $\square$ & $\square$ & $\square$ \\
\hline Se despierta con un despertador & $\square$ & $\square$ & $\square$ \\
\hline Se despierta enfadado & $\square$ & $\square$ & $\square$ \\
\hline
\end{tabular}




\begin{tabular}{|l|c|c|c|}
\hline Le despiertan adultos u otros hermanos & $\square$ & $\square$ & $\square$ \\
\hline Le cuesta salir de la cama a la mañana & $\square$ & $\square$ & $\square$ \\
\hline Le lleva mucho tiempo espabilarse & $\square$ & $\square$ & $\square$ \\
\hline Se despierta muy temprano por la mañana & $\square$ & $\square$ & $\square$ \\
\hline Tiene buen apetito por la mañana & $\square$ & $\square$ & $\square$ \\
\hline
\end{tabular}

\section{Sueño durante el dia}

\begin{tabular}{|l|c|c|c|}
\hline & $\begin{array}{c}\text { Habitualmente } \\
\mathbf{( 5 - 7} \\
\text { dias/semana) }\end{array}$ & $\begin{array}{c}\text { A veces } \\
(2-4 \text { dias } \\
\text { semana) }\end{array}$ & $\begin{array}{c}\text { Raro } \\
(\mathbf{0 - 1} \\
\text { días/semana) }\end{array}$ \\
\hline Echa la siesta & $\square$ & $\square$ & $\square$ \\
\hline $\begin{array}{l}\text { Se queda dormido de repente en mitad de } \\
\text { actividades (juegos, paseos, etc.) }\end{array}$ & $\square$ & $\square$ & $\square$ \\
\hline Parece cansado & $\square$ & $\square$ & $\square$ \\
\hline
\end{tabular}

Durante la pasada seman su hijo ha estado muy adormilado o se ha quedado dormido en las siguientes circunstacias (anotar el que corresponda):

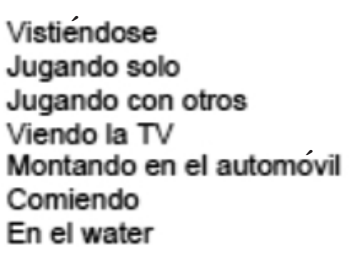

\section{Adormilado Dormido}

$\begin{array}{ll}\square & \square \\ \square & \square \\ \square & \square \\ \square & \square \\ \square & \square \\ \square & \square \\ \square & \square\end{array}$

Adaptado de: Lucas de la Cruz L, Martínez-Vizcaino V, Álvarez-Bueno C, Arias-Palencia N, et al. Reliability and validity of the Spanish version of the Children's Sleep Habits Questionnaire (CSHQ-SP) in school-age children. Child Care Health Dev. 2016;42(5):675-82. 


\section{ANNEX 6}

\section{Questionnaire for parents about the usefulness of sleep hygiene strategies}

(Developed by the authors)

1. Did you have a chance to read the manual of ideas to sleep better?
a. Yes.
b. No.

2. If you did not, why?
a. I did not get the e-mail.
b. I could not open the manual file.
c. I found it too long.
d. It is difficult to understand.
e. I was not interested.
f. Other.

3. If you selected "Other," indicate the reason.

4. If you read the manual, were you able to implement any of the ideas?
a. Yes.
b. No.

5. Indicate which ideas you implemented
a. Organize a routine.
b. Relaxing activities before bedtime.
c. Visual schedule.
d. Less screen use and/or down lights before bedtime.
e. Calm environment.
f. Avoid stimulating beverages or food before bedtime.
g. Avoid long naps.
h. Increase activities performed outdoors and with natural light in the morning.
i. Drink less liquids before bedtime.
j. Other.

6. If you selected "Other," indicate which one.

7. Is your child sleeping better?
a. Yes.
b. No.

8. Which ideas did you find useful?
a. Organize a routine.
b. Relaxing activities before bedtime.
c. Visual schedule.
d. Less screen use and/or down lights before bedtime.
e. Calm environment.
f. Avoid stimulating beverages or food before bedtime.
g. Avoid long naps.
h. Increase activities performed outdoors and with natural light in the morning.
i. Drink less liquids before bedtime.
j. Other.
9. If you selected "Other," indicate which one.
10. Is sleep still a problem for you?
a. It is not a problem.
b. It is a mild problem.
c. It is a moderate problem.
d. It is a severe problem.
e. It is a major problem. 


\section{ANNEX 7}

\section{Questionnaire about sleep during the COVID-19 lockdown}

(Developed by the authors)

1. In your opinion, has your child's sleep become a problem during the lockdown?
a. It is not a problem.
b. It is a mild problem.
c. It is a moderate problem.
d. It is a severe problem.
e. It is a major problem.

2. How many people share your household?

3. During the lockdown, ¿how many hours does the child use screens per day?

4. Does the child fall asleep while using a screen (mobile phone, TV)?
a. Frequently (5-7 days/week).
b. Sometimes (2-4 days/ week).
c. Rarely (0-1 day/week).

5. If in kindergarten/school, is the child asked to do activities at home?
a. Frequently (5-7 days/week).
b. Sometimes (2-4 days/ week).
c. Rarely (0-1 day/week).

6. If the child was receiving any treatment (speech therapy, educational psychology, psychology, etc.), was it possible to stay in contact with the therapists?
a. Frequently (1-2 days/ week or more).
b. Sometimes (2-4 days/month).
c. Rarely (1 day/month).
d. Never.
e. My child did not have a therapeutic team.

7. Was the child able to do activities during the day with natural light? For example, in the backyard.
a. Frequently (5-7 days/week).
b. Sometimes (2-4 days/ week).
c. Rarely (0-1 day/week).

8. Were you able to maintain a night routine to help the child sleep?
a. Frequently (5-7 days/week).
b. Sometimes (2-4 days/week).
c. Rarely (0-1 day/week).
d. We never had a night routine to help the child sleep.

9. Does the child go to bed at the same time every night? (A maximum difference of 1 hour between days is considered the same time).
a. Frequently (5-7 days/ week).
b. Sometimes (2-4 days/ week).
c. Rarely (0-1 day/week).

10. What time does the child go to bed? (If at different times, indicate the most frequent time).

11. How long (in minutes) does it take the child to fall asleep after going to bed?

12. Does the child struggle at bedtime (cries, refuses to stay in bed, etc.)?
a. Frequently (5-7 days/ week).
b. Sometimes (2-4 days/ week).
c. Rarely (0-1 day/week).

13. Is the child afraid of sleeping alone?
a. Frequently (5-7 days/ week).
b. Sometimes (2-4 days/week).
c. Rarely (0-1 day/week). 
14. Is the child afraid of sleeping with the lights off?
a. Frequently (5-7 days/week).
b. Sometimes (2-4 days/week).
c. Rarely (0-1 day/ week).

15. Does the child wet the bed during the night?
a. Frequently (5-7 days/week).
b. Sometimes (2-4 days/ week).
c. Rarely (0-1 day/ week).

16. Does the child sleepwalk?
a. Frequently (5-7 days/week).
b. Sometimes (2-4 days/week).
c. Rarely (0-1 day/ week).

17. During the night, does the child change bedrooms?
a. Frequently (5-7 days/ week).
b. Sometimes (2-4 days/ week).
c. Rarely (0-1 day/ week).

18. Does the child sleep in the parents' / caregivers' bed?
a. Frequently (5-7 days/week).
b. Sometimes (2-4 days/week).
c. Rarely (0-1 day/week).

19. Did the child have, while sleeping, any episode of crying, being frightened, or you had a hard time calming them down or waking them up?
a. Frequently (5-7 days/week).
b. Sometimes (2-4 days/ week).
c. Rarely (0-1 day/week).

20. Does the child wake up alarmed by a frightening dream?
a. Frequently (5-7 days/week).
b. Sometimes (2-4 days/ week).
c. Rarely (0-1 day/week).

21. How many hours does the child sleep per night?

22. In relation to sleep hours, do you think the child...?
a. Sleeps the right amount.
b. Sleeps little.
c. Sleeps too much.

23. Does the child wake up during the night?
a. Frequently (5-7 days/week).
b. Sometimes (2-4 days/ week).
c. Rarely (0-1 day/ week).

24. What time does the child wake up in the morning?

25 . Does the child wake up angry?
a. Frequently (5-7 days/week).
b. Sometimes (2-4 days/week).
c. Rarely (0-1 day/ week).

26. Does the child fall asleep during the day while doing other activities? For example, while eating or playing.
a. Frequently (5-7 days/ week).
b. Sometimes (2-4 days/week).
c. Rarely (0-1 day/ week). 
27. Does the child take a nap?
a. Frequently (5-7 days/ week).
b. Sometimes (2-4 days/week).
c. Rarely (0-1 day/week).

28. During the lockdown, did you notice you had a mood change?
a. I get angry more often.
b. I feel sadder.
c. I have trouble sleeping.
d. I did not notice any change.
e. I feel fine, I like spending more time with my children.

29. Did you have any problem keeping or getting a job during the lockdown?
a. Yes.
b. No.

30. Did you have to leave the child at the care of someone else during the lockdown? (Because you were sick, you are a healthcare worker or other reason.)
a. Yes.
b. No. 


\section{ANNEX 8}

\section{Approach to sleep during the pediatric visit}

(Developed by the authors)

Sleep health promotion at each visit

$\sqrt{ }$

At each visit, ask the family about:

- Child's sleep characteristics

- Concerns about their child's sleep

Review guidelines on sleep hygiene and discuss potential strategies: Bedtime routine keeping a regular schedule, reducing screen exposure, increasing exposure to natural light, organizing nap time.

\section{Consider:}

- Child's history

- Family characteristics

- Physical environment

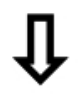

Assess other strategies:

Check for associations useful to sleep, going to bed later and restricting time in bed, positive reinforcement, "bedtime pass", gradual wait.

Based on their routine 